\title{
Influence of Water Stress and Rhizobial Inoculation on Accumulation of Proline in Selected Cultivars of Phaseolus vulgaris (L.)
}

\author{
Eutropia V. Tairo $^{1 *}$, Kelvin M. Mtei ${ }^{2}$ and Patrick A. Ndakidemi ${ }^{1}$ \\ ${ }^{1}$ Department of Sustainable Agriculture and Biodiversity Management, The Nelson Mandela \\ African Institution of Science and Technology, P.O. Box 447, Arusha, Tanzania \\ ${ }^{2}$ Department of Water and Environmental Sciences, The Nelson Mandela African Institution of \\ Science and Technology, P.O. Box 447, Arusha, Tanzania \\ *Corresponding author
}

\begin{tabular}{|c|c|}
\hline \multirow[b]{3}{*}{ Keywords } & A B S T R A C T \\
\hline & \multirow{6}{*}{$\begin{array}{l}\text { A two season field experiment and a single season screen house experiment were } \\
\text { conducted to assess the effect of water stress periods and rhizobial inoculation in five ( } 5 \text { ) } \\
P \text {. vulgaris (L.) cultivars. The experiment consisted of } 2 \text { levels of rhizobia (with and } \\
\text { without inoculation), two stress levels (With and without stress) and five cultivars of } P \text {. } \\
\text { vulgaris (L.) (KAT B9, KAT B1, F9 Kidney Selection, F8 Drought Line and JESCA). The } \\
\text { field experiment was conducted for two consecutive seasons, while the screen house study } \\
\text { was done in a season. Results showed that proline content ( } \mu \text { mol } \mathrm{g}^{-1} \text {.FW) was higher in } \\
\text { inoculated and water stressed treatments. Variety number } 4(F 8 \text { Drought Line) and } 5 \\
(J E S C A) \text { significantly recorded higher proline content in field experiment as compared to } \\
\text { the rest. However, in the screen house experiment, variety } 2(K A T B I) \text { and } 4 \text { (F8 Drought } \\
\text { Line) significantly accumulated more proline than the other tested varieties. Significant } \\
\text { interactive effects were also observed between inoculation, water stress periods and the } \\
\text { tested } P \text {. vulgaris varieties. }\end{array}$} \\
\hline & \\
\hline $\begin{array}{l}\text { Drought, Common } \\
\text { bean, Inoculants, } \\
\text { Varieties, Water. }\end{array}$ & \\
\hline Article Info & \\
\hline $\begin{array}{l}\text { Accepted: } \\
\text { 20 February } 2017 \\
\text { Available Online: } \\
10 \text { March } 2017\end{array}$ & \\
\hline & \\
\hline
\end{tabular}

\section{Introduction}

Proline is an organic osmolyte, $\mathrm{N}$ containing compound which stand as osmoprotection agent involved in reducing oxidative damage in plants by reducing free radicals (Tatar and Gevrek, 2008; Matysik et al., 2002). Apart from acting as an osmolyte, proline accumulation has other important cell functions. Proline tends to act as $\mathrm{N}$ source in the cell under stress conditions, where the accumulation of this nitrogenous compound could be utilized as a form of stored $\mathrm{N}$ (Dandekar and Uratsu, 1988). Under condition of $\mathrm{N}$ deficit, proline accumulation in plant declines which implies that the degradation of proline is influenced by the stimulation of the enzyme proline dehydrogenase. However, under condition of sufficient $\mathrm{N}$, proline level increase due to the action of ornithine, signifying majority of the ornithine pathway over the glutamine pathway, in addition to the inhibition of proline dehdrogenase activity (Sánchez, et al., 2002). Elboutahiri et al., (2010) reported that Rhizobium inoculated alfalfa had the highest leaf proline levels. Generally, N deficiency is characterized by a decrease in proline accumulation in plant tissues, essentially 
because the degradation of proline is favoured by the stimulation of proline dehdrogenase. Proline in plant is synthesized mainly from glutamate (pyrroline-5-carboxylate (P5C), synthetase (P5CS) and P5C reductase (P5CR) and converted back into glutamate by proline dehydrogenase (PDH) and P5C dehydrogenase (Szabados and Savoure, 2009; Delauney and Verma, 1993; Kishor et al., 2008). From the above background, inoculating legumes with appropriate rhizobial strain may result in more accumulation of proline in plant tissues and hence rendering them tolerant to water stress.

Abiotic stress condition such as water limitation in higher plants result in huge accumulation of plant osmolytes mainly proline and glycine betaine (Kavikishor et al., 2005). Majority of plants accumulate compatible osmolytes like proline (Pro), Glycine betaine and sugar alcohols, when they are exposed to water stress and/or drought (Tatar and Gevrek, 2008). Proline among other amino acids is commonly produced in higher plants and generally accumulates in large extent in response to environmental stresses (Ashraf and Foolad, 2007). Proline play a very important role in plants, a part of osmolyte for osmotic adjustment, it stabilize sub cellular structures such as membrane and proteins and scavenging free radicals (Matysik et al., 2002; Tatar and Gevrek, 2008; Mafakheri et al., 2010). It also contribute in alleviating cytoplasmic acidosis and maintaining appropriate $\mathrm{NADP}^{+} / \mathrm{NADPH}$ ratios compatible with metabolism (Hare and Cress, 1997). According to Stewart (1981), proline does not hamper with normal biochemical reactions but allows the plants to survive under stress. Studies have reveal that proline perform as solute during stress, where an increase in the proline content would indicate resistance or tolerance to water deficit, serve as parameter for the assortment of highly resistant cultivars (Bates et al., 1973). For example, the proline content increased under drought stress in pea (Sanchez et al., 1998). In higher plants, accumulated proline can have many other important functions, prevention of membrane disintegrations and enzyme inactivation in the environment of low water activity.

Once plants accumulate proline in their tissues, the proline tends to reduce the toxic effects of ions in enzymes activity and also lowers the generation of free radicals formed by abiotic stresses (Siddiqui et al., 2015). The theory behind proline is therefore very useful to assess the physiological status and more generally to understand stress tolerance in plants species. Therefore the aim of this work is to assess the effects of water stress/drought among the five (5) common bean varieties as influenced by stress phases and rhizobial inoculation respectively.

\section{Materials and Methods}

\section{Description of site location}

The trial was conducted at Agricultural Seed Agency (ASA) farm in Arusha, located at Latitude $3^{\circ} 18^{\prime} \mathrm{S}$ and Longitude $36^{\circ} 38^{\prime} 06.29^{\prime \prime}$ E.ASA receives the mean annual rainfall of $819 \mathrm{~mm}$, mean temperature of $19.15^{\circ} \mathrm{C}$ with relative humidity of about $94 \%$ and altitude of 1520 m.a.s.l. The field trial was carried out during dry season of January, to March 2014 and January, to March, 2015 while the screen house experiment was carried out from mid January to March, 2016 under irrigation.

\section{Experimental design and treatment application}

The experiment was designed in split, split plot with 3 replications. The plot size was $3 \mathrm{x}$ $4 \mathrm{~m}$. The field experimental treatments 
consisted of 2 levels of Rhizobia (with and without inoculation) as the main factor followed by imposing of stress (sub factor) in vegetative and flowering stages of plant growth. Five cultivars of $P$. vulgaris (L.) (KAT B9, KAT B1, F9 Kidney Selection, F8 Drought Line and JESCA) were assigned to sub-sub plots. The common bean seeds were sown at a spacing of $50 \mathrm{~cm} \times 20 \mathrm{~cm}$, making a plant population density of 200,000 plants per hectare. The BIOFIX legume inoculants were obtained from $M E A$ Company Nairobi-Kenya, sold under license from the University of Nairobi. Common bean seeds lines and/or varieties KAT B9, KAT B1, F9 Kidney Selection, F8 Drought Line and JESCA were obtained from the breeding unit based at Selian Agricultural Research Institute (SARI), Arusha, Tanzania.

Land for field experiment was cleared and all the necessary practices like ploughing and harrowing were done before planting. Moreover, in the screen house experiment, wooden box technique was used to establish the experiment. This was done by collecting the same soil used at field experiment and beans were planted using the protocol developed by Agbicodo et al., (2009) with some modifications. Common bean seeds were thoroughly mixed with $R$. leguminosarum inoculants to supply $\left(10^{9}\right.$ cells/g seed), following procedure stipulated by products manufacturer. To avoid contamination, all non-inoculated seeds were sown first, followed by inoculated seeds. Three seeds were sown and thinned to two plants per hill after full plant establishment. Stress period of 10 days were imposed at vegetative and flowering stages of plant growth by not irrigating.

\section{Plant harvest and sample preparation}

Plant leaf samples from field and glasshouse experiments were collected for proline analysis. In the field experiment, 10 plants were randomly sampled from the middle rows of each plot while in the glasshouse experiment two plants from each pot were sampled. The fresh plant leaf samples from each of the growth stages (i.e. vegetative and flowering) were collected from the third young leaf from the top and kept in ice container to maintain their freshness for proline determination.

\section{Determination of proline contents in plant leaves}

Extraction of proline contents in plant leaves was done as described by Bates et al., (1973). Extract of $0.5 \mathrm{~g}$ of plant material were homogenized in $10 \mathrm{~mL}$ of $3 \%$ aqueous sulphosalicylic acid. The homogenate were filtered through Whatman No. 2 filter paper. The $2 \mathrm{~mL}$ of filtrate were taken in a test tube and $2 \mathrm{~mL}$ of glacial acetic acid were added followed by $2 \mathrm{~mL}$ acid ninhydrin. The mixture was then heated in the boiling water bath for 1 hour. The reaction was then terminated by placing the tube in ice bath and $4 \mathrm{~mL}$ of toluene was added to the reaction mixture and stirred well for 20-30 seconds. The toluene layer was separated and warmed to room temperature. The red color intensity was then measured at $520 \mathrm{~nm}$ using $2800 \mathrm{UV} / \mathrm{V}$ is Spectrophotometer. Standard curve were then prepared and the amount of proline in the test sample were obtained from the standard curve. The proline content on fresh-weight basis was calculated as follows; $\mu$ moles/gram tissues $=[(\mu$ gproline $/ \mathrm{ml}) \times \mathrm{ml}$ toluene $) / 115.5 \mu \mathrm{g} / \mu \mathrm{mole}] /[(\mathrm{g}$. sample $) / 5]$

\section{Statistical analysis}

A 3-way ANOVA was used to analyze data collected. The analysis was done using STATISTICA software programof 2013. Fisher's least significant difference was used to compare treatment means at $p=0.05$ (Steel and Torrie, 1980). 


\section{Results and Discussion}

Effect of inoculation with R.leguminosarum biovar phaseoli and stress periods on proline content in selected $P$. vulgaris $(\mathrm{L}$.) varieties

Significance increase in proline content $(\mu \mathrm{mol}$ $\mathrm{g}^{-1} . \mathrm{FW}$ ) was observed in inoculated compared with non-inoculated treatments (Table $1 \& 2$ ). Rhizobial inoculation significantly increased proline content during vegetative stage by $12 \%$ and $8 \%$ in season one and two respectively (Table 1). In screen house experiment, inoculation with Rhizobium strain increased the proline content by $34 \%$ in vegetative stage and $31 \%$ in flowering stage when compared with un inoculated treatments (Table 2). Water stress treatments significantly increased proline content by 35 and $39 \%$ in season one and by 33 and $48 \%$ in season two at vegetative and flowering stages respectively (Table 1 ). In the screen house experiment, water stress treatment increased the proline levels in plants by $36 \%$ and $49 \%$ during the flowering and vegetative phases (Table 2).

Table.1 Proline content ( $\mu \mathrm{mol}$ g-1.FW) in P. vulgaris (L.) plant leaves as influenced by water stress periods and rhizobial inoculation in field experiment for two consecutive seasons

\begin{tabular}{|c|c|c|c|c|}
\hline \multicolumn{3}{|l|}{$1^{\text {st }}$ Season } & \multicolumn{2}{|c|}{$2^{\text {nd }}$ Season } \\
\hline Growth Phases & Vegetative & Flowering & Vegetative & Flowering \\
\hline \multicolumn{5}{|l|}{$\begin{array}{l}\text { Treatments } \\
\text { inoculation }\end{array}$} \\
\hline $\mathbf{R}+$ & $4.39 \pm 0.31 \mathrm{a}$ & $5.65 \pm 0.29 a$ & $4.96 \pm 0.25 \mathrm{a}$ & $5.70 \pm 0.43 \mathrm{a}$ \\
\hline R- & $4.36 \pm 0.23 a$ & $4.95 \pm 0.28 b$ & $4.57 \pm 0.24 b$ & $5.65 \pm 0.55 \mathrm{a}$ \\
\hline \multicolumn{5}{|l|}{ Stress Levels } \\
\hline StrL1 & $3.45 \pm 0.15 b$ & $4.02 \pm 0.23 b$ & $3.81 \pm 0.11 \mathrm{~b}$ & $3.88 \pm 0.18 b$ \\
\hline StrL 2/StrL 3 & $5.30 \pm 0.25 \mathrm{a}$ & $6.58 \pm 0.10 \mathrm{a}$ & $5.72 \pm 0.22 \mathrm{a}$ & $7.47 \pm 0.48 \mathrm{a}$ \\
\hline \multicolumn{5}{|l|}{ Varieties } \\
\hline Vrty 1 & $3.82 \pm 0.32 \mathrm{c}$ & $4.80 \pm 0.53 b$ & $4.06 \pm 0.35 b$ & $4.58 \pm 0.57 \mathrm{c}$ \\
\hline Vrty 2 & $3.63 \pm 0.38 \mathrm{c}$ & $4.87 \pm 0.46 b$ & $4.42 \pm 0.30 \mathrm{~b}$ & $4.55 \pm 0.41 \mathrm{c}$ \\
\hline Vrty 3 & $4.16 \pm 0.26 b c$ & $4.89 \pm 0.47 b$ & $4.32 \pm 0.25 b$ & $3.97 \pm 0.45 c$ \\
\hline Vrty 4 & $4.58 \pm 0.25 b$ & $6.12 \pm 0.35 \mathrm{a}$ & $5.69 \pm 0.45 \mathrm{a}$ & $6.43 \pm 0.90 b$ \\
\hline Vrty 5 & $5.69 \pm 0.59 a$ & $5.83 \pm 0.40 \mathrm{a}$ & $5.32 \pm 0.37 \mathrm{a}$ & $7.84 \pm 0.97 \mathrm{a}$ \\
\hline \multicolumn{5}{|c|}{$\begin{array}{l}\text { 3-Way Anova (F- } \\
\text { Statistics) }\end{array}$} \\
\hline $\mathrm{Rhz}$ & $0.02 \mathrm{~ns}$ & $17.24 * * *$ & $5.58 *$ & $0.02 \mathrm{~ns}$ \\
\hline StrL & $67.67 * * *$ & $227.86 * * *$ & $135.86 * * *$ & $88.80 * * *$ \\
\hline Vrty & $10.50 * * *$ & $10.80 * * *$ & $14.83^{* * *}$ & $11.33 * * *$ \\
\hline Rhz*StrL & $0.004 \mathrm{~ns}$ & $2.23 \mathrm{~ns}$ & $0.87 \mathrm{~ns}$ & $1.54 \mathrm{~ns}$ \\
\hline Rhz*Vrty & $1.03 \mathrm{~ns}$ & $0.87 \mathrm{~ns}$ & $0.35 \mathrm{~ns}$ & $0.38 \mathrm{~ns}$ \\
\hline StrL*Vrty & $1.37 \mathrm{~ns}$ & $3.06^{*}$ & $4.15 * *$ & $3.48^{*}$ \\
\hline Rhz*StrL*Vrty & $2.11 \mathrm{~ns}$ & $1.50 \mathrm{~ns}$ & $0.34 \mathrm{~ns}$ & $0.52 \mathrm{~ns}$ \\
\hline
\end{tabular}

$+\mathrm{R}$ : With $R$. leguminosarum, $-\mathrm{R}$ : Without $R$. leguminosarum; StrL 1: No water stress. StrL 2: Water stress at Vegetative Stage. StrL 3: Water stress at Flowering Stage. Vrty 1: KAT B9. Vrty 2: KAT B1. Vrty 3. F9 Kidney Selection. Vrty 4: F8 Drought Line. Vrty 5: JESCA. Values presented are means \pm SE. *, $* * * * *=$ significant at $p \leq$ 0.05 , at $p \leq 0.01$ and at $p \leq 0.001$ respectively, $\mathrm{ns}=$ Not significant. Means followed by similar letter(s) in a given column are not significantly difference from each other at $p=0.05$. 
Table. 2 Proline content ( $\mu \mathrm{mol}$ g-1.FW) in P. vulgaris (L.) plant leaves as influenced by water stress periods and rhizobial inoculation in the screen house

\begin{tabular}{lll}
\hline Growth Phases & Vegetative & Flowering \\
\hline Treatments inoculation & & \\
R+ & $4.60 \pm 0.47 \mathrm{a}$ & $5.20 \pm 0.49 \mathrm{a}$ \\
R- & $3.03 \pm 0.43 \mathrm{~b}$ & $3.57 \pm 0.42 \mathrm{~b}$ \\
\hline Stress levels & & \\
StrL 1 & $2.98 \pm 0.43 \mathrm{~b}$ & $2.98 \pm 0.43 \mathrm{~b}$ \\
StrL 2/StrL 3 & $4.66 \pm 0.46 \mathrm{a}$ & $5.79 \pm 0.41 \mathrm{a}$ \\
\hline Varieties & & \\
Vrty 1 & $2.62 \pm 0.71 \mathrm{~b}$ & $3.72 \pm 0.89 \mathrm{a}$ \\
Vrty 2 & $5.34 \pm 0.76 \mathrm{a}$ & $5.13 \pm 0.61 \mathrm{a}$ \\
Vrty 3 & $2.99 \pm 0.67 \mathrm{~b}$ & $4.69 \pm 0.74 \mathrm{a}$ \\
Vrty 4 & $4.08 \pm 0.70 \mathrm{ab}$ & $4.09 \pm 0.77 \mathrm{a}$ \\
Vrty 5 & $4.06 \pm 0.71 \mathrm{ab}$ & $4.27 \pm 0.73 \mathrm{a}$ \\
\hline 3-Way Anova (F-Statistics) & & \\
Rhz & $7.80^{* *}$ & $8.29 * *$ \\
StrL & $8.97 * *$ & $24.58^{* * *}$ \\
Vrty & $2.87 *$ & $0.75 \mathrm{~ns}$ \\
Rhz*StrL & $0.18 \mathrm{~ns}$ & $0.09 \mathrm{~ns}$ \\
Rhz*Vrty & $0.70 \mathrm{~ns}$ & $1.07 \mathrm{~ns}$ \\
StrL*Vrty & $0.69 \mathrm{~ns}$ & $0.48 \mathrm{~ns}$ \\
Rhz*StrL*Vrty & $3.27 *$ & $1.63 \mathrm{~ns}$ \\
\hline
\end{tabular}

$+\mathrm{R}$ : With $R$. leguminosarum; .-R: Without $R$. leguminosarum, StrL 1: No water stress. StrL 2: Water stress at Vegetative Stage. StrL 3: Water stress at Flowering Stage. Vrty 1: KAT B9. Vrty 2: KAT B1. Vrty 3. F9 Kidney Selection. Vrty 4: F8 Drought Line. Vrty 5: JESCA. Values presented are means \pm SE. *, $* *, * * *=$ significant at $p \leq$ 0.05 at $p \leq 0.01$ and at $p \leq 0.001$ respectively, ns $=$ Not significant. Means followed by similar letter(s) in a given column are not significantly difference from each other at $p=0.05$.

Fig.1 Interactive effects of stress level and five (5) P. vulgaris (L.) on proline content ( $\mu \mathrm{mol} \mathrm{g}^{-}$ ${ }^{1}$.FW) in season (1) field experiment at flowering stage, StrL 2-: Control, StrL 3-: Water stress at flowering stage, Vrty 1-: KAT B9, Vrty 2-: KAT B1, Vrty 3-: F9 Kidney Selection, Vrty 4-: F8

Drought Line, Vrty 5-: JESCA)

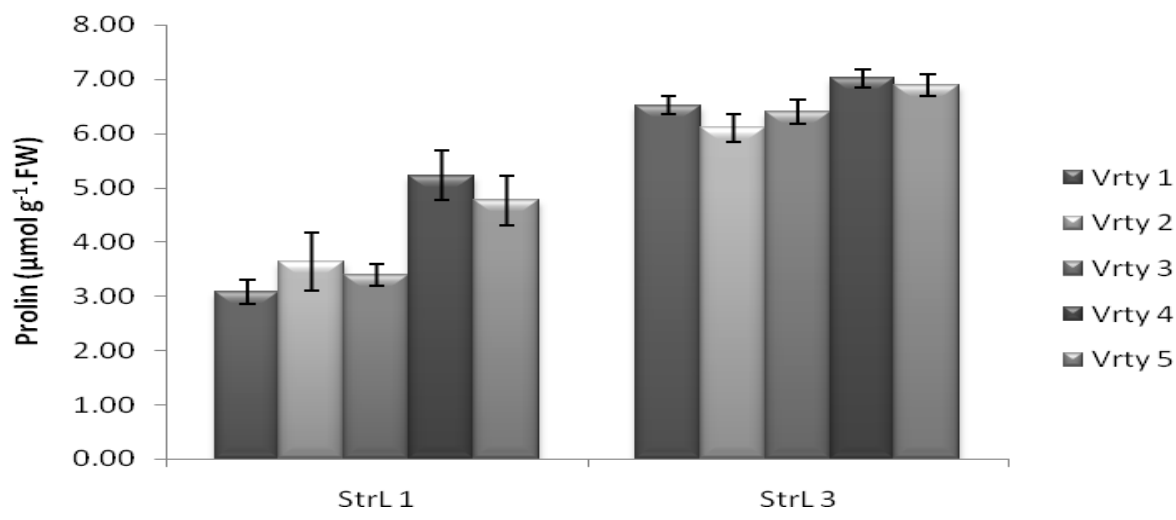


Fig.2 Interactive effects of stress level and five (5) P. vulgaris L. on proline content $\left(\mu \mathrm{mol} \mathrm{g}{ }^{-1}\right.$.FW) in season (2) field experiment at vegetative stage, StrL 1-: Control, StrL 2-: Water stress at vegetative stage, Vrty 1-: KAT B9, Vrty 2-: KAT B1, Vrty 3-: F9 Kidney Selection, Vrty 4-: F8 Drought Line, Vrty 5-: JESCA)

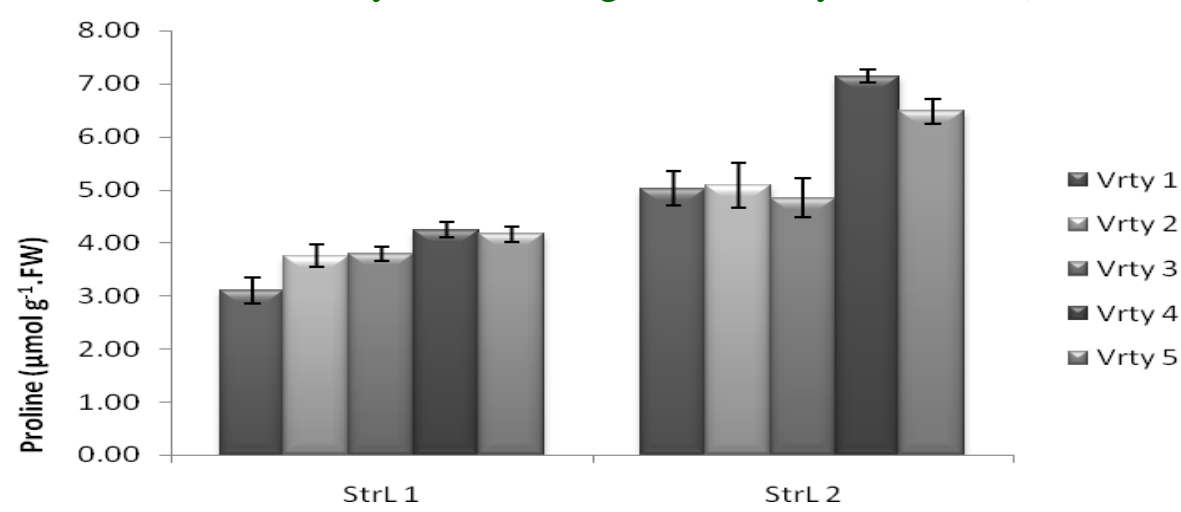

Fig.3 Interactive effects of stress level and five (5) P. vulgaris (L.) on proline content ( $\mu \mathrm{mol} \mathrm{g}^{-}$ ${ }^{1}$.FW) in season (2) field experiment at flowering stage, StrL 1-: Control, StrL 3-: Water stress at flowering stage, Vrty 1-: KAT B9, Vrty 2-: KAT B1, Vrty 3-: F9 Kidney Selection, Vrty 4-: F8 Drought Line, Vrty 5-: JESCA)

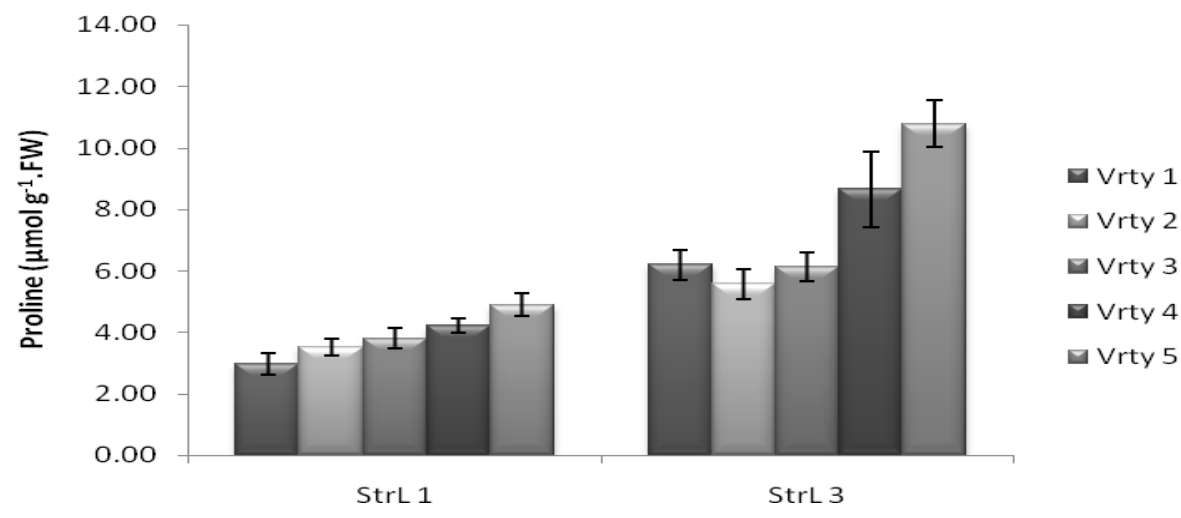

Fig.4 Interactive effects of rhizobial inoculation, stress level and five (5) P. vulgaris (L.) on proline content ( $\mu \mathrm{mol} \mathrm{g}{ }^{-1}$.FW) screen house experiment at vegetative stage, R--: Without rhizobial inoculation, R+-: With rhizobial inoculation, StrL 1-: Control, StrL -: Water stress at vegetative stage, V1=Vrty1-: KAT B9, V2=Vrty 2-: KAT B1, V3=Vrty 3-: F9 Kidney Selection, V4=Vrty 4-: F8 Drought Line, V5=Vrty 5-: JESCA)

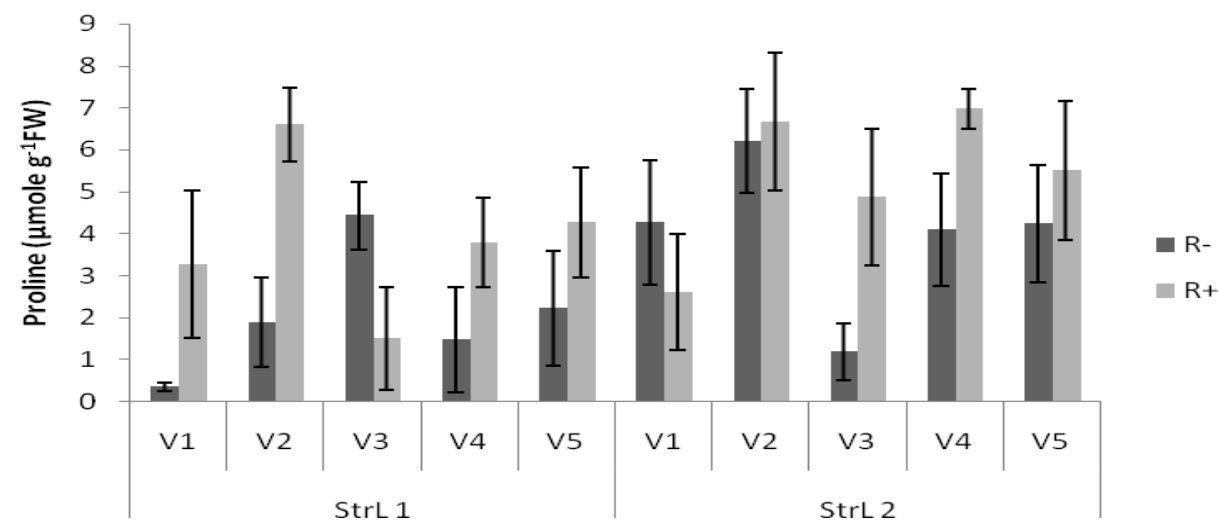


Significant increase in proline content $(\mu \mathrm{mol}$ $\left.\mathrm{g}^{-1} . \mathrm{FW}\right)$ was also recorded in variety $4(F 8$ Drought Line) and 5 (JESCA) in field experiment, in season 1 and 2 respectively (Table 1). However, in the screen house experiment the proline content in bean varieties was as follows; KAT B1>F8 Drought Line >JESCA > F8 Kidney Selection > KAT B9 (Table 2).

Interactive effects of inoculation with $R$. leguminosarum biovar phaseoli and stress period on proline content in selected $\boldsymbol{P}$. vulgaris (L.) varieties

In the field experiments, there was significant interaction between stress levels and variety in proline content ( $\mu \mathrm{mol} \mathrm{g}^{-1}$.FW) (Fig. 1, $2 \&$ 3). However, significant interaction was observed in the screen house between rhizobial inoculation, stress and bean varieties during the vegetative stage (Figure 4). Generally, the water stressed and rhizobial inoculated treatments had increased proline.

Rhizobial inoculation significantly improved proline content ( $\mu \mathrm{mol} \mathrm{g}^{-1} . \mathrm{FW}$ ) of $P$. vulgaris (L.) as compared with non-inoculated treatment. Studies by other researchers (Daniel et al., 2007; Djibril et al., 2005; Kirda et al., 1989; Ramos et al., 2005; Sassi-Aydi and Abdelly, 2012) have also reported elevated level of proline under condition of sufficient $\mathrm{N}$ in which the proline levels increased in the tissues due to the action of ornithine pathway in enhancing proline synthesis, over the glutamine pathway (Sánchez et al., 2002). Elboutahiri et al., (2010) reported that Rhizobium inoculation in alfalfa resulted in highest leaf proline levels. Another study by Kohl et al., (1991) in Glycine max plants inoculated with Bradyrhizobium japonicum showed higher amounts of proline in their tissues similar to what was found in this study. There was significance increase in proline content $(\mu \mathrm{mol}$ $\left.\mathrm{g}^{-1} . \mathrm{FW}\right)$ in water stress treatment as compared with un-stressed water treatment. Research evidence has shown that proline is commonly produced in higher plants and generally accumulates in large extent in response to environmental stresses such as water stress and /or drought (Ashraf and Foolad, 2007; Kapuya et al., 1995; Lobato et al., 2008; Siddiqui et al., 2015; Tatar and Gevrek, 2008) and hence serving as a bio indicator of resistance or tolerance to water deficit (Bates et al., 1973). In a closely related study, Sanchez et al., (1998) reported increased proline content in pea plants subjected to drought stress.

Variety 4 (F8 Drought line), 5 (JESCA) and 2 $(K A T$ B1) significantly increased proline content $\left(\mu \mathrm{mol} \mathrm{g}^{-1} . \mathrm{FW}\right)$ of $P$. vulgaris $\mathrm{L}$. in field and screen house experiment as compared with the other studied varieties. It has being established that accumulation of proline in plant tissues has been used as a biomarker and a parameter of choice for water stress tolerance in plants. This is due to the fact that water stressed plants produce proline as an adaptive and survival mechanism under water stress conditions (Chiang and Dandekar, 1995; Farooq et al., 2009; Ford, 1984; Hayat et al., 2012; Jaleel et al., 2007; Masoudi-Sadaghiani et al., 2011; Verbruggen and Hermans, 2008).The significantly higher amount of proline in variety 4 ( $F 8$ Drought line), 5 (JESCA) and 2 (KAT B1) suggests the potential of involving them in more advanced studies related to drought. Furthermore, the interactive effects between rhizobial inoculation, water stress and variety 4 ( $F 8$ Drought line), 5 (JESCA) and 2 (KAT B1) in producing elevated levels of proline is an indication which may warrant further studies.

It can be concluded from this study, rhizobial inoculation and water stress increased proline content in P. vulgaris (L.) Furthermore, the proline content was higher in varieties number 4 (F8 Drought line), 5 (JESCA) and 2 (KAT B1) and hence indicating their potential 
to tolerate drought. Interactive effects between rhizobial inoculation, water stress and few identified varieties in enhancing the proline levels in the plants is an indication of various factors which may play a significant role in developing appropriate technology related to water stress tolerance in $P$. vulgaris.

\section{Acknowledgement}

This study was supported by the Government of Tanzania under the umbrella of Nelson Mandela African Institution of Science and Technology (NM-AIST) - Tanzania. Arusha Agricultural Seed Agency (ASA) is acknowledged for providing the study site.

\section{References}

Agbicodo, E.M., Fatokun, C.A., Muranaka, R.G.F., Visser, R.G.F., and Linden van der, C.G. 2009. Breeding drought tolerant cowpea; constraints, accomplishments, and future prospects. Euphytica, 167: 353-370.

Ashraf, M., Foolad, M.R. 2007. Roles of glycine betaine and proline in improving plant abiotic stress resistance. Environ. Exp. Bot., 59(2): 206-216.

Bates, L.S., Waldran, R.P., Teare, I.D. 1973. Rapid determination of free proline for water stress studies. Plant Soil., 39: 205-208.

Chiang, H.H., Dandekar, A.M. 1995. Regulation of proline accumulation in Arabidopsis thaliana (L.) Heynh during development and in response to desiccation. Plant Cell Environ., 18: 1280-1290.

Dandekar, A.M., Uratsu., S.L., 1988. A simple base pair change in proline biosynthesis genes causes osmotic stress tolerance. J. Bacteriol., 170: 5943-5945

Daniel, M., Pierre, F., Ruben, L., Ana, Z., Alain, P., Cesar, A.I., Esther, M.G.,
2007. Nitrogen Fixation Control under Drought Stress. Localized or Systemic? Plant Physiol., 143(4): 1968-1974.

Delauney, A.J., Verma, D.P.S. 1993. Proline biosynthesis and osmoregulation in plants. The Plant J., 4(2): 215-223.

Djibril, S., Mohamed, O.K., Diaga, D., Diégane, D., Abaye, B.F., Maurice, S., Alain, B. 2005. Growth and development of date palm (Phoenix dactylifera L.) seedlings under drought and salinity stresses. Afr. J. Biotechnol., 4: 968-972.

Elboutahiri, N., Thami-Alami, I., Udupa, S.M. 2010. Phenotypic and genetic diversity in Sinorhizobium meliloti and $S$. medicae from drought and salt affected regions of Morocco. $B M C$ Microbiol., 10: 15.

Farooq, M., Wahid, A., Kobayashi, N., Fujita, D., Basra, S.M.A. 2009. Plant drought stress: effects, mechanisms and management. Agron. Sustain. Dev., 29: 185-212.

Ford, C. W. (1984). Accumulation of low molecular weight solutes in water stressed tropical legumes. Phytochem., 23: 1007-1015.

Hare, P.D., Cress, W.A. 1997. Metabolic implications of stress-induced proline accumulation in plants. Plant Growth Regul., 21: 79-102.

Hayat, S., Hayat, Q., Alyemeni, M.N., Wani, A.S., Pichtel, J., Ahmad, A. 2012. Role of proline under changing environments. Plant Sign. \& Behav., 7(11): 1456-1466.

Jaleel, C.A., Gopi, R., Sankar, B., Manivannan, P., Kishorekumar, A., Sridharan, R., Panneerselvam, R. 2007. Studies on germination, seedling vigour, lipid peroxidation and proline metabolism in Catharanthus roseus seedlings under salt stress. South Afr. J. Bot., 73: 190-195. 
Kapuya, J.A., Barendse, G.W.M., Linskens, H.F. 1995. Water stress tolerance and proline accumulation in Phaseolus vulgaris. Acta Bot. Neerl., 34: 295-300.

Kavikishor, P.B., Sangam, S., Amrutha, R.N., Sri Laxmi, P., Naidu, K.R., Rao, K.R.S.S., Rao, S., Reddy, K.J., Theriappan, P., Sreenivasulu, N. 2005. Regulation of proline biosynthesis, degradation, uptake and transport in higher plants: It's Implication in plant growth \& abiotic stress tolerance. 88(3): 424-438.

Kirda, C., Danso, S.K.A., Zapata, F., 1989. Temporal water stress effects on nodulation, nitrogen accumulation and growth of soybean. Plant Soil., 120:4955.

Kishor, P.B.K., Sangama, S., Amrutha, R.N., Laxmi, P.S., Naidu, K.R., Rao, K.S. 2005. Regulation of proline biosynthesis degradation, uptake and transport in higher plants: its implications in plant growth and abiotic stress tolerance. Curr. Sci., 88: 424-438.

Kohl, D.H., Kennelly, D.J., Zhy, Y., Schubert, K.R., Sheader, G. 1991. Proline accumulation, nitrogenase $(\mathrm{C} 2 \mathrm{H} 2$ reducing) activity and activities of enzymes related to proline metabolism in drought-stressed soybean nodules. J. Exp. Bot., 42: 831-837.

Lobato, A.K.S., Oliveira Neto, C.F., Costa, R.C.L., Santos Filho, B.G., Cost, R.C.L., Cruz, F.J.R., Neves, H.K.B., Lopes, M.J.S. 2008. Physiological and biochemical behavior in soybean (Glycine max cv. Sambabia) plants under water deficit. Aust. J. Crop Sci., 2: $25-23$

Mafakheri, A., Siosemardeh, A., Bahramnejad, B., Struik, P.C., Sohrabi, Y. 2010. Effect of drought stress on Yield, Proline and Chlorophyll contents in three chickpea cultivars, Aust. J. Crop Sci., 4(8): 580-585.
Masoudi-Sadaghiani, F., Abdollahi, M. B., Zardoshti M. R., Rasouli-Sadaghiani M. H., Tavakoli, A. 2011. Response of proline, soluble sugars, photosynthetic pigments and antioxidant enzymes in potato (Solanum tuberosum L.) to different irrigation regimes in greenhouse condition. Aust. J. Crop Sci., 5(1):55-60.

Matysik, J.A., Bhalu, B., Mohanty, P. 2002. Molecular mechanism of quenching of reactive oxygen species by proline under stress in plants. Curr. Sci., 82(5): 525-532.

Ramos, M.L.G., Parsons, R., Sprent, J.I. 2005. Differences in ureide and amino acid content of water stressed soybean inoculated with Bradyrhizobium japonicum and B. elkanii. Pesquisa Agropecuária Brasileira., 40: 453-458.

Sánchez, E., Garcia P.C., López-Lefebre, L.R., Rivero, R.M., Ruiz, M.R., Romero, L. 2002. Proline metabolism in response to nitrogen deficiency in French Bean plants (Phaseolus vulgaris L. cv Strike). Plant Growth Regul., 36: 261-265.

Sanchez, F.J., Manzanares, M., de Andres, E.F., Tenorio, J.L., Ayerbe, L. 1998. Turgor maintenance, osmotic adjustment and soluble sugar and praline accumulation in 49 pea cultivars in response to water stress. Field Crops Res., 59: 225-235.

Sassi-Aydi, S., Abdelly, C. 2012. Inoculation with the native Rhizobium gallicum $8 \mathrm{a} 3$ improves osmotic stress tolerance in common bean drought-sensitive cultivar. Acta Agriculturae Scandinavica Section B -Soil and Plant Sci., 62: 179-187.

Siddiqui, M.H., Al-Khaishany, M.Y., AlQutami, M.A., Al-Whaibi, M.H., Grover, A., Ali, H.M., Al-Wahibi, M.S., Bukhari, N.A. 2015. Response of Different Genotypes of Faba Bean Plant 
to Drought Stress. Int. J. Mol. Sci., 16:10214-10227. 10.33901ijms160510214.

doi

Steel, R. G. D., Torrie, J. H., 1980. Principles and Procedures of Statistics: A Biometrical Approach, 2nd Edition, McGraw Hill, New York.

Stewart, C.R., 1981. Proline accumulation: Biochemical aspects. In: Paleg LG, Aspinall D (Eds), Physiology and Biochemistry of drought resistance in plants. Pp. 243-251.
Szabados, L., Savoure, A., 2009. Proline: a multifunctional amino acids, Trends in Plant Sci., 15(2): 89-97.

Tatar, O., Gevrek, M.N., 2008. Influence of Water Stress on Proline Accumulation, Lipid Peroxidation and Water Content of Wheat. Asian J. Plant Sci., 7(4):409412.

Verbruggen, N., Hermans, C. 2008. Proline accumulation in plants: a review. Amino Acids., 35: 753759.

\section{How to cite this article:}

Eutropia V. Tairo, Kelvin M. Mtei and Patrick A. Ndakidemi. 2017. Influence of Water Stress and Rhizobial Inoculation on Accumulation of Proline in Selected cultivars of Phaseolus vulgaris (L.). Int.J.Curr.Microbiol.App.Sci. 6(3): 2205-2214. doi: https://doi.org/10.20546/ijcmas.2017.603.251 